\title{
Pod growth of Two Genotypes of Country Bean (Lablab purpureus L.) in Acid Soil
}

\author{
Sharifunnessa Moonmoon*, Md. Moudud Ahmod, Md. Sazidur Rahman
}

Department of Crop Botany and Tea Production Technology, Faculty of Agriculture, Sylhet Agricultural University, Sylhet-3100, Bangladesh

DOI: $10.36347 /$ sjavs.2020.v07i04.001

| Received: 19.03.2020 | Accepted: 27.03.2020 | Published: 05.04.2020

*Corresponding author: Sharifunnessa Moonmoon

Abstract

Original Research Article

Pod growth of two genotypes (Sikribi Sheem-01 and SB003) of Country bean (Lablab purpureus L.) were investigated
to assess the time of harvest of vegetable pod at PM. The field experiment was laidout in randomized complete block
design with three replication. The harvested pods were collected to the laboratory and randomly split into samples ( 5
pod/samples) of three replication. Pod growth was observed at $33,40,47,54$ and 61 days after flowering (DAF).
Analysis of variance (ANOVA) of different parameters were calculated using R software (R Gui x 643.6 .0 ). Pod size
increased gradually with increasing ages (DAF) and reached maximum at PM. Pericarp fresh weight reached
maximum at around 40 DAF (approximately $7.14 \mathrm{~g}$ and $6.78 \mathrm{~g}$ per pod in Sikribi Sheem-01 and SB003 genotypes,
respectively. Percent dry matter was highest in 61 DAF in both the genotypes. Pod and pericarp ratio was gradually
increased with the increase of DAF. It may be concluded that Lablab bean can harvested between 33 DAF to 40 DAF
for vegetable pod purpose, as pod weight will ensure market price and fleshy soft pericarp will ensure consumption
satisfaction.
Keywords: Lablab purpureus, Pod harvesting stage, Pod growth, Vegetable pod, Acidic soil.
Copyright @ 2020: This is an open-access article distributed under the terms of the Creative Commons Attribution license which permits unrestricted
use, distribution, and reproduction in any medium for non-commercial use (NonCommercial, or CC-BY-NC) provided the original author and source
are credited.

\section{INTRODUCTION}

Country bean (Lablab purpureus L.), a selfpollinated [1] legumes under Fabaceae family [2] is believe to be originated as wild from in india [3] and native of Asia and Africa, widely distributed throughout tropics and subtropics including Bangladesh [4]. This underexploited nutritious perennial legume cultivated as annual for green pod vegetable purpose [5] containing $3.8 \%$ protein green pod basis [3]. The twining, creeping vine strain is in marginal land, home garden [6] homesteads, including in urban areas, for centuries in Bangladesh [7]. Although it is a highly proteinous major legume vegetable of winter [4]. In Bangladesh, summer growing varieties are developed [7] for its tender green pods [8] for serving throughout the year. This multifarious legume $[9,10]$ has several forms of use includes eating young pods, seeds, leaves, and flowers [6]. Green pods are used as vegetables, mature seeds as pulse [8] and dried seeds are eaten directly after frying [10] which has high protein content (21-29 percent) [7]. As a dietary vegetable, country bean have high nutritional values similar to most of edible legumes [11]. The country having scarce of animal protein can rely on legumes to meet up the deficiency [1]. In developing country, green mature pods of country bean is comparatively inexpensive source of protein than animal source [12] which can play an important role in protein supplementation in Bangladesh [10]. As a vegetable legume, both edible pods and seed of country bean provide substantial amount of protein with dietary fibre, carbohydrate, fat, vitamins and minerals [13,8]. A large tonnage of green pods and mature seeds are also exporting on demand to many countries including the UK [7]. For vegetable, usually green tender pod producing varieties are grown and long pods similar to kidney beans are preferred as vegetables [5]. In lablab bean high pod mass accounts for higher amount of important constituents present during harvesting. With increasing moisture content, individual pod weight increases [14]. Moisture content plays important role in regulating shelf life of pod too. Again low moisture content of pod indicates high dry matter content [15] with higher dietary fibre and protein. Thus moisture and dry matter gradient regulates the harvesting of lablab in appropriate condition. But there was not much of a work conducted on determining appropriate time to harvest of lablab vegetable pod in Bangladesh. Some work has been done in India [16] and Mymenshingh, Bangladesh condition which were varied possibly due to location, genotype and growing condition [12]. Physiological maturity is appropriate time for vegetable seed purpose harvesting 
were varied from 33 DAF to 40 DAF [12]] in Bangladesh. But pericarp attain maximum weight earlier than seed [12], thus days for vegetable pod purpose harvesting may not be the same with PM. Therefore, it was necessary to find out the right harvesting time of vegetable lablab bean for consumption and also for exporting in acidic soil in Bangladesh.

\section{MATERIALS AND METHOD}

The experiment was conducted under AgroEcological Zone of Eastern Surma-Kushiyara Floodplain (AEZ-20) during winter season (November 2019 to February 2020) at field laboratory of department of crop botany and tea production technology, Sylhet Agricultural University, Sylhet $\left(24^{\circ} 54^{\prime} 37.8^{\prime \prime} \mathrm{N} 91^{\circ} 54^{\prime} 00.6^{\prime \prime E}\right)$. The elevation of the experimental area is $30 \mathrm{~m}$ above the sea level, belonging "Khadimnagar" soil series having $\mathrm{pH}$ value of 5.1. Two genotypes of lablab bean viz. Sikribi Sheem-01 (G1) and SB003 (G2) was collected from the department of Horticulture, Sylhet Agricultural University. The field experiment was laidout in randomized complete block design with three replication. Each block was consisted of four plot comprises of two genotypes, each one having one pit each. The size of each plot was $2 \mathrm{~m}^{2}(2 \mathrm{~m}$ x $1 \mathrm{~m})$ that was $8 \mathrm{~m}^{2}(8 \mathrm{~m} \mathrm{x} 1 \mathrm{~m})$ for each block. $0.5 \mathrm{~m}$ distance was maintained between block to block. The pit was dug out $(50 \mathrm{~cm} \mathrm{X} 50 \mathrm{~cm}$ X $50 \mathrm{~cm})$ and left for sundry. The soil was pulverized well and mixed with well decomposed cowdung (3.20 kg/pit) as well as Triple super phosphate $(0.06 \mathrm{~kg} / \mathrm{pit})$ as basal dose. Five seeds were sown in each pit and after germination two seedlings were left over while rest was thinned out. At 20, 30 and 40 days after germination, Urea and Muriate of Potash were top dressed at the rate of $0.02 \mathrm{~kg} / \mathrm{pit}$ and $0.06 \mathrm{~kg} /$ pit respectively in three splits. For supporting the plant, $8 \mathrm{~m}$ long and $1 \mathrm{~m}$ width trellis for each block was made with bamboo plant. In order to track pod age at various days after flowering (33 DAF, $40 \mathrm{DAF}, 47$ DAF, 54 DAF and 61 DAF), the flowers were tagged in the days of blooming with woolen threads of various color. At the specified age (different DAF), 10 pods were collected from each block randomly for one genotypes that is $30 \mathrm{pod} / \mathrm{genotypes}$ from three block. The harvested pods were brought to the laboratory and randomly split into samples (5 pod/samples) of three replication. At each pod ages of two genotypes, data was collected on pod length, pod width using centimeter scale, pod weight (fresh and dry), pericarp weight (fresh and dry) uses electronics balance. Pod materials were dried using oven at $82^{\circ} \mathrm{C}$ temperature for 72 hours to obtain dry weight for further calculation. Two genotypes and different aged pod (DAF) was used as treatment in this experiment. Dry matter percentage $(\% \mathrm{DM})$ of pod and pericarp were calculated using following equation- $\% \mathrm{DM}=\frac{\text { Dryweight }(g)}{\text { Fresh weight }(g)} \times 100$,

Percentage were calculated using following equation- $\% \mathrm{~A}$ in $\mathrm{B}=\frac{A \text { (unit) }}{B(\text { Unit })} \mathrm{X} 100$,

Ratio were calculated using following equation- $\mathrm{A}: \mathrm{B}=\frac{A(\text { unit })}{B(\text { unit })}$,

Analysis of variance (ANOVA) of different parameters was calculated using R software (R Gui x 64 3.6.0). Duncan's Multiple Range Test was performed to evaluate the mean differences. Level of significance and $\mathrm{t}$-value waer measured by paired samples test.

\section{RESULTS}

Pod length does not increase significantly after 33 DAF of age rather decreases in some degree after 47 DAF (table 1). Although in terms of genotypes, length was higher $(11.31 \mathrm{~cm})$ in $\mathrm{G} 2$ than $\mathrm{G} 1(10.09 \mathrm{~cm})$. Considering the pod width, width of the G1 was higher $(3.29 \mathrm{~cm})$ than $\mathrm{G} 2(2.59 \mathrm{~cm})$. It increases and become maximum at 40 DAF than follows trend of decreasing in interaction (Table 1).

Table-1: Combined effect of Genotype \& Pod maturity stage on size and weight of two genotypes of Country bean (Dolichos lablab)

\begin{tabular}{|c|c|c|c|c|c|c|c|c|}
\hline \multirow[t]{2}{*}{ Treatment } & \multicolumn{2}{|c|}{ Pod size $(\mathrm{cm})$} & \multicolumn{3}{|c|}{ pod weight (g) } & \multicolumn{3}{|c|}{ Pericarp weight (g) } \\
\hline & length & width & Fresh weight & Dry weight & $\% \mathrm{DM}$ & Fresh weight & Dry weight & $\% \mathrm{DM}$ \\
\hline G1 X 33 DAF & $9.61 \mathrm{~b}$ & $3.13 \mathrm{~b}$ & $9.39 \mathrm{~b}$ & $1.33 \mathrm{e}$ & $14.20 \mathrm{e}$ & $7.01 \mathrm{a}$ & $0.75 \mathrm{ab}$ & $10.75 \mathrm{~b}$ \\
\hline G1 X 40 DAF & $9.88 \mathrm{~b}$ & $3.29 \mathrm{a}$ & $10.51 \mathrm{a}$ & $1.77 \mathrm{~d}$ & $16.85 \mathrm{de}$ & $7.14 \mathrm{a}$ & $0.75 \mathrm{ab}$ & $10.49 \mathrm{~b}$ \\
\hline G1 X 47 DAF & $10.09 \mathrm{~b}$ & $3.18 \mathrm{~b}$ & $9.32 \mathrm{bc}$ & $2.03 \mathrm{~b}$ & $21.80 \mathrm{~cd}$ & $5.55 \mathrm{~b}$ & $0.54 \mathrm{~d}$ & $9.77 \mathrm{~b}$ \\
\hline G1 X 54 DAF & $9.64 \mathrm{~b}$ & $3.05 \mathrm{c}$ & $8.24 \mathrm{~d}$ & $2.12 \mathrm{ab}$ & $25.84 \mathrm{bc}$ & $4.36 \mathrm{c}$ & $0.52 \mathrm{de}$ & $12.34 \mathrm{~b}$ \\
\hline G1 X 61 DAF & $7.19 \mathrm{~d}$ & $2.14 \mathrm{f}$ & $2.57 \mathrm{f}$ & $1.99 \mathrm{bc}$ & $77.37 \mathrm{a}$ & $0.57 \mathrm{~d}$ & $0.49 \mathrm{de}$ & $84.58 \mathrm{a}$ \\
\hline G2 X 33 DAF & $11.31 \mathrm{a}$ & $2.46 \mathrm{e}$ & $8.23 \mathrm{~d}$ & $1.02 \mathrm{f}$ & $12.41 \mathrm{e}$ & $6.78 \mathrm{a}$ & $0.73 \mathrm{ab}$ & $10.74 \mathrm{~b}$ \\
\hline $\mathrm{G} 2 \mathrm{X} 40 \mathrm{DAF}$ & $11.18 \mathrm{a}$ & $2.59 \mathrm{~d}$ & $9.00 \mathrm{bcd}$ & $1.31 \mathrm{e}$ & $14.57 \mathrm{e}$ & $6.77 \mathrm{a}$ & $0.79 \mathrm{a}$ & $11.62 \mathrm{~b}$ \\
\hline G2 X 47 DAF & $11.13 \mathrm{a}$ & $2.53 \mathrm{de}$ & $8.57 \mathrm{~cd}$ & $1.74 \mathrm{~d}$ & $20.33 \mathrm{~cd}$ & $5.56 \mathrm{~b}$ & $0.68 \mathrm{bc}$ & $12.24 \mathrm{~b}$ \\
\hline G2 X 54 DAF & $10.95 \mathrm{a}$ & $2.54 \mathrm{~d}$ & $7.28 \mathrm{e}$ & $2.23 \mathrm{a}$ & $30.98 \mathrm{~b}$ & $3.72 \mathrm{c}$ & $0.62 \mathrm{c}$ & $17.11 \mathrm{~b}$ \\
\hline G2 X 61 DAF & $9.09 \mathrm{c}$ & $1.62 \mathrm{~g}$ & $2.50 \mathrm{f}$ & $1.85 \mathrm{~cd}$ & $74.36 \mathrm{a}$ & $0.53 \mathrm{~d}$ & $0.45 \mathrm{e}$ & $86.64 \mathrm{a}$ \\
\hline
\end{tabular}

Within particular treatments, figures within a column having similar letter(s) do not differ significantly at P $\leq 0.05$ by DMRT; $\uparrow$ : DAF-Days after flowering, G1 (Sikribi sheem-1) and G2 (SB003) 
Genotype 1 performed well as gave higher fresh weight $\left(10.51 \mathrm{~g} \mathrm{pod}^{-1}\right)$ and dry weight $\left(2.03 \mathrm{~g} \mathrm{pod}^{-}\right.$ $\left.{ }^{1}\right)$ than second genotypes $\left(9.00 \mathrm{~g} \mathrm{pod}^{-1}\right.$ and $2.23 \mathrm{~g} \mathrm{pod}^{-1}$ respectively) (Table 1). Mean fresh weight of the single pod of genotypes increases and become maximum $(9.76$ g) at $40 \mathrm{DAF}$ than decreases gradually. In case of dry weight of pod, it is $54 \mathrm{DAF}$ (2.18 g) than follows same trend. Fleshy pericarp goes with the trend of fresh weight of pod in terms of both fresh and dry weight, that is attain maximum weight at 40 DAF but statistically at 33 DAF in both genotypes (Table 1). The ratio between pod and pericarp was gradually increasing and become maximum (fresh 4.61 \& dry 4.09 ), signifies that mass of fleshy pericarp decreases inversely with increasing pod mass after $33 \mathrm{DAF}$ in both fresh and dry weight basis. \% pericarp in pod validate the fact as it was maximum at $33 \mathrm{DAF}$ in both fresh $(78.51 \%)$ and dry $(64.10 \%)$ weight basis and decreases afterward.

Table-2: Assimilate partitioning of pod at different seed maturity stages in two genotypes of Country bean

\begin{tabular}{|l|l|l|l|l|l|l|l|l|}
\hline \multirow{2}{*}{ Treatment } & \multicolumn{2}{l|}{ Pod:pericarp } & \multicolumn{2}{l|}{ \%pericarp in pod } & \multicolumn{2}{l|}{ Pericarp:seed } & \multicolumn{2}{l|}{ Pod:seed } \\
\cline { 2 - 9 } & fresh & Dry & fresh & Dry & Fresh & Dry & Fresh & Dry \\
\hline G1 $\times 33 \mathrm{DAF}$ & 1.34 & $1.77 \mathrm{~d}$ & $74.65 \mathrm{~b}$ & $56.54 \mathrm{~b}$ & $2.96 \mathrm{~b}$ & $1.31 \mathrm{bc}$ & $3.96 \mathrm{bc}$ & $2.31 \mathrm{bc}$ \\
\hline $\mathrm{G} 1 \times 40 \mathrm{DAF}$ & 1.47 & $2.37 \mathrm{c}$ & $67.89 \mathrm{c}$ & $42.29 \mathrm{c}$ & $2.12 \mathrm{c}$ & $0.74 \mathrm{~cd}$ & $3.12 \mathrm{~cd}$ & $1.74 \mathrm{~cd}$ \\
\hline $\mathrm{G} 1 \times 47 \mathrm{DAF}$ & 1.68 & $3.75 \mathrm{ab}$ & $59.48 \mathrm{~d}$ & $26.65 \mathrm{~d}$ & $1.47 \mathrm{cde}$ & $0.36 \mathrm{~d}$ & $2.47 \mathrm{def}$ & $1.36 \mathrm{~d}$ \\
\hline $\mathrm{G} 1 \times 54 \mathrm{DAF}$ & 1.9 & $4.08 \mathrm{a}$ & $52.71 \mathrm{e}$ & $24.73 \mathrm{~d}$ & $1.12 \mathrm{def}$ & $0.33 \mathrm{~d}$ & $2.12 \mathrm{efg}$ & $1.33 \mathrm{~d}$ \\
\hline $\mathrm{G} 1 \times 61 \mathrm{DAF}$ & 4.49 & $4.10 \mathrm{a}$ & $22.34 \mathrm{f}$ & $24.40 \mathrm{~d}$ & $0.29 \mathrm{f}$ & $0.32 \mathrm{~d}$ & $1.29 \mathrm{~g}$ & $1.32 \mathrm{~d}$ \\
\hline $\mathrm{G} 2 \times 33 \mathrm{DAF}$ & 1.22 & $1.41 \mathrm{~d}$ & $82.36 \mathrm{a}$ & $71.66 \mathrm{a}$ & $4.64 \mathrm{a}$ & $2.75 \mathrm{a}$ & $5.60 \mathrm{a}$ & $3.75 \mathrm{a}$ \\
\hline $\mathrm{G} 2 \times 40 \mathrm{DAF}$ & 1.33 & $1.67 \mathrm{~d}$ & $75.2 \mathrm{~b}$ & $60.32 \mathrm{~b}$ & $3.23 \mathrm{~b}$ & $1.57 \mathrm{~b}$ & $4.27 \mathrm{~b}$ & $2.57 \mathrm{~b}$ \\
\hline G2 $247 \mathrm{DAF}$ & 1.54 & $2.56 \mathrm{c}$ & $64.91 \mathrm{c}$ & $39.09 \mathrm{c}$ & $1.89 \mathrm{~cd}$ & $0.64 \mathrm{~cd}$ & $2.90 \mathrm{de}$ & $1.64 \mathrm{~cd}$ \\
\hline G2 $\times 54 \mathrm{DAF}$ & 2 & $3.64 \mathrm{~b}$ & $50.47 \mathrm{e}$ & $27.56 \mathrm{~d}$ & $0.99 \mathrm{ef}$ & $0.38 \mathrm{~d}$ & $1.95 \mathrm{fg}$ & $1.38 \mathrm{~d}$ \\
\hline G2 $\times 61 \mathrm{DAF}$ & 4.73 & $4.07 \mathrm{a}$ & $21.22 \mathrm{f}$ & $24.62 \mathrm{~d}$ & $0.30 \mathrm{f}$ & $0.33 \mathrm{~d}$ & $1.44 \mathrm{~g}$ & $1.33 \mathrm{~d}$ \\
\hline
\end{tabular}

Within particular treatments, figures within a column having similar letter(s) do not differ significantly at $\mathrm{P} \leq 0.05$ by DMRT; $\uparrow$ : DAFDays after flowering, G1 (Sikribi sheem-1) and G2 (SB003)

Pericarp mass decreases but pod mass still increases are because of continuous assimilates accumulation in seed. Both the ratio result viz. pericarp: seed and pod: seed shows decreasing trends after 33 DAF, signifies pod accumulates mass only in seed after that time. Genotype 1 is fleshier than genotype 2 (Table 2).

\section{DISCUSSION}

Pod length does not increases significantly after 33DAF of age rather decreases in some degree after 47 DAF that is similar what Das \& Fakir [12] has found. The pod length was within the range that was reported $(2.5$ to $14.0 \mathrm{~cm}$ ) by Pengelly \& Maass [5]. Considering the pod width, width of the G1 was higher than G2 supports what have has found previously [8]. Genotype 1 performed well as gave higher fresh and dry weight than second genotypes. The fresh pod weight was within the range of $7.08 \mathrm{~g}$ to $12.61 \mathrm{~g}$ that is recorded by [1] among 44 genotypes which support our current research. Fresh weight was similar (40 DAF) but dry weight was somewhat dissimilar (40 DAF) with the result has been recorded by [12]. But fleshy pericarp goes with the trend of fresh weight of pod in terms of both fresh and dry weight, that is attain maximum weight at 40 DAF but statistically at 33 DAF in both genotypes which support what have fakir have found. Pericarp mass decreases but pod mass still increases are because of continuous assimilates accumulation in seed. Both the ratio result viz. pericarp: seed and pod: seed shows decreasing trends after $33 \mathrm{DAF}$, signifies pod accumulates mass only in seed after that time.

\section{CONCLUSION}

The experiment showed after 33 DAF pod length did not increase significantly but width increased up to 40 DAF in these two genotypes. Although G2 is longer but G1 shows better potential in width, pod weight (fresh \& dry); that increases gradually and become maximum at $40 \mathrm{DAF}$ in fresh weight due to moisture and 54 DAF in dry weight at both genotypes. Fleshy pericarp attains maximum weight (fresh \& dry) at $40 \mathrm{DAF}$ in these genotypes. Although pod fresh weight increases up to $40 \mathrm{DAF}$ due to increase seed mass accumulation but percentage of pericarp in pod and fleshiness decreases after 33 DAF. In these genotypes and agro-ecological basis Lablab bean can harvested between $33 \mathrm{DAF}$ to $40 \mathrm{DAF}$ for vegetable pod purpose as pod weight will ensure market price and fleshy soft pericarp will ensure consumption satisfaction. Higher pod masses in this period indicate pod may contain higher percentage of dietary fiber, protein, fat, carbohydrates and mineral. Due to slightly lower moisture in the pod harvested in this period, shelf life of harvested pod could be higher comparatively.

\section{REFERENCES}

1. Barua H, Rahman MH, Patwary MA, Alam MZ, Nahar S. Variations in growth and yield of indigenous hyacinth bean (Lablab purpureus (L.) sweet) genotypes. The Agriculturists. 2014;12(2):01-5.

2. Hossain S, Ahmed R, Bhowmick S, Al Mamun A, Hashimoto M. Proximate composition and fatty acid analysis of Lablab purpureus (L.) legume 
seed: implicates to both protein and essential fatty acid supplementation. Springerplus. 2016 Dec;5(1):1-0.

3. Parmar AM, Singh AP, Dhillon NP, Jamwal M. Genetic variability of morphological and yield traits in dolichos bean (Lablab purpureus L.). African Journal of Agricultural Research. 2013;8(12):1022-7.

4. Salim M, Hossain S, Alam S, Rashid JA, Islam S. Estimation of genetic divergence in lablab bean (Lablab purpureus L.) genotypes. Bangladesh Journal of Agricultural Research. 2013 Jun 4;38(1):105-14.

5. Pengelly BC, Maass BL. Lablab purpureus (L.) Sweet-diversity, potential use and determination of a core collection of this multi-purpose tropical legume. Genetic Resources and Crop Evolution. 2001 Jun 1;48(3):261-72.

6. Morris JB. Morphological and reproductive characterization in hyacinth bean, Lablab purpureus (L.) Sweet germplasm with clinically proven nutraceutical and pharmaceutical traits for use as a medicinal food. Journal of dietary supplements. 2009 Jan 1;6(3):263-79.

7. Morris JB. Morphological and reproductive characterization in hyacinth bean, Lablab purpureus (L.) Sweet germplasm with clinically proven nutraceutical and pharmaceutical traits for use as a medicinal food. Journal of dietary supplements. 2009 Jan 1;6(3):263-79.

8. Mohan N, Aghora TS. Evaluation of Dolichos (Lablab purpureus L.) germplasm for pod yield and pod related traits. Journal of Horticultural Sciences. 2009;4(1):50-3.

9. Maass BL. Changes in seed morphology, dormancy and germination from wild to cultivated hyacinth bean germplasm (Lablab purpureus: Papilionoideae). Genetic Resources and Crop Evolution. 2006 Sep 1;53(6):1127-35.

10. Mortuza MG, Tzen JT. Physicochemical and functional properties of ten cultivars of seem (Lablab purpureus L.), an underexploited bean in Bangladesh. Journal of the Science of Food and Agriculture. 2009 Jun;89(8):1277-83.

11. Cui B, Hu Z, Zhang Y, Hu J, Yin W, Feng Y, Xie $\mathrm{Q}$, Chen G. Anthocyanins and flavonols are responsible for purple color of Lablab purpureus (L.) sweet pods. Plant physiology and biochemistry. 2016 Jun 1;103:183-90.

12. Das SS, Fakir MS. Pod growth and seed composition in two genotypes of Lablab purpureus. Legume Research-An International Journal. 2014;37(3):306-10.

13. Kumar A, Lal A, Semwal AD. Effect of Microwave Drying on Nutritional and Antinutritional Factors of Dolichos Lablab Beans. International Journal of Science, Engineering and Technology. 2016;4:711-5.

14. Simonyan KJ, Yiljep YD, Oyatoyan OB, Bawa GS. Effects of moisture content on some physical properties of Lablab purpureus (L.) sweet seeds. Agricultural Engineering International: CIGR Journal. 2009 Jul 22.

15. Deka RK, Sarkar CR. Nutrient composition and antinutritional factors of Dolichos lablab L. seeds. Food chemistry. 1990 Jan 1;38(4):239-46.

16. Murthy P, Kumar BM. Studies on seed development and physiological maturity in held bean \{lablab purpureus (L.) sweet\}. Legume Research-An International Journal 2004;27(2):134-6. 